\section{SIMPLY ANOTHER AMERICAN MYTH REVISITED *}

\section{Chalermsri Chantasingh *}

\section{Introduction}

In his article on the relationships among literature, culture, and the history of a people, "Literature and the Historian," R. Gordon Kelly discusses the legitimacy and validity of using literary texts as historical evidence. He states that a literary text can serve as indicator of several social parameters of a culture and of a people who produce and selectively preserve it. Because literary works are cultural products, they should, therefore, be understood in the context of the cultures for which they are intended.

Literary works as a class of cultural artifacts must be understood historically (as opposed to critically) in the context of the groups which produced them and responded to them.

(Kelly in American Quarterly, Vol. 26:2, 149).

Within the above paradigm, The King and $I$ can then be classified as an American cultural artifact. It is evidently

\footnotetext{
* This paper is an adaptation of part of the author's study entitled "The Americanization of THE KING AND I" (1999)

" Ph. D. Lecturer, English Department, Faculty of Arts, Silpakorn University, Nakorn Pathom, Thailand.
}

an Americanized story written for an American public. The response from its audiences over time confirms its social significance in American society. In its first production, this musical ran for 1,246 shows (03/29/50-03/20/54, St James Theatre). In comparison, Guys and Dolls, which received the Critics Circle Award for the best play of the season, opened earlier in the same season $(11 / 24 / 50-11 / 25 / 53,46$ th St. Theatre), and lasted for 1,200 performances. Both musicals were revived for the 1976-1977 season. Guys and Dolls ran for only 239 shows (07/ 21/76-02/13/77, Broadway Theatre) and was declared a flop. The revival of The King and $I$, on the other hand, ran for 719 shows $(05 / 02 / 77-12 / 30 / 78$, Uris Playhouse) and was declared a hit (Rosenberg and Harburg; 1993: 324). In 1985 it was revived again and ran for 191 shows (01/07/85-06/30/85, Broadway). Of the nine musicals in the 1985 season, it was the only revival declared a hit. Evidently The King and $I$ contains something that was extraordinarily appealing to American audiences over time.

This paper attempts to trace the four "cultural propensities" which ensure the popularity of The King and I (1951) and its 'progenitors' in American society. It will also discuss the role of the entertainment industry in the propagation of the Anna myth and legend.

\section{Four Cultural Propensities}

Kelly's paradigm that a literary piece should be understood historically in the context of the groups that produce and respond to it asserts the inter-relatedness between a literary piece and the contextual audiences to which it has 
been directed. In reverse, what can this literary piece tell us about the American people and its society? What are the underlying aspects in this narrative that make it appealing to the American public over time?

To search for the answer to the above query, we need to look, on the one hand, into the interplay of the narrative, theme, and characterization and the audiences' reception of them, and, on the other hand, how those narrative characteristics affect their audiences. Then we can perceive the "cultural propensities" of this story that are congruent with the underlying or unspoken American sentiments. In the case of the musical The King and I, there are four predominant cultural propensities that work effectively with the American audiences.

\section{Heroism and hero worship}

People's love for heroism and hero worship is not anything new. Thomas Carlyle in his compilation of essays, "On Heroes, Hero-Worship, and the Heroic in History" (1993), states that "[w]orship of a hero is transcendent admiration of a Great Man" (Carlyle, 11). He contends that "heroes" in numerous societies have been transformed into objects of worship. For example, the Norse made the god Odin from their national hero, in the similar manner that Napoleon, the French military hero, was made emperor for his people from the ashes of the French Revolution (Goldberg, 1993: 1x-lxi; and Carlyle, 22-23). Michael Goldberg, Carlyle's editor, agrees with him that hero worship was "an ultimate creed of mankind" (Goldberg, 1993: 1xi).
Hero worship is not alien to the American people either. There exist several historical and national heroes, such as George Washington, Thomas Jefferson, Benjamin Franklin, and Martin Luther King, Jr. There also exist "mythical" heroes, such as Davy Crockett, Kit Carson, and Buffalo Bill. These figures are a creative blend of fact and imagination, whose life stories survive by means of literary works about them.

What purpose do these heroes, either dead or alive, serve in a community? Theodore L. Gross in his enlightening book, The Heroic Ideal in American Literature (1977), maintains that literary heroes "dramatize the moral texture" of a nation. Although they are merely artistic creations of the imagination, these heroes embody "the unspoken ideals, the undesired terrors, the dream life and the mundane existence of their readers." Gross also contends that by discovering the meaning of their characters, by analyzing the roots of their behavior, we can discern the moral fabric of a nation (Gross, 1977: v). Gross explains that American social heroes are usually exceptionally courageous and active men who seek to realize an ideal, with passions more intense than those of the people whom they represent (Gross, 8 and 34).

The hero of American literature must certainly struggle and view his experience with perception; but he must, in some sense, be extraordinary, and he must pursue an ideal - in protest or in accommodation to some form of authority (Gross, viii).

The exemplification of this idea is available in several pieces of popular 
entertainment, from the animated cartoon character, Mickey Mouse, to the loner-hero in such movies like Mr. Smith Goes to Washington (1939), Sergeant York (1941), Shane (1953), Superman (1978), and Forrest Gump (1994). These are archetypal Hollywood creations of heroes. They have to battle the odds, overcome forces of evileither within or without - and reaffirm the spirit of the American dream. More importantly, such movies "testify to the significant affinity between the American audience and such characters" (Scott, 1996: 232).

The American love for heroes and heroworship has been manipulated successfully in other areas in the society as well. In athletics, for example, American sentiments for heroism and hero-worship is manifested in the industry's creation of the star-system, focusing on particular star athletes even in team sports like basketball or football, instead of emphasizing team effort and sportsmanship as desirable values.

This emphasis on the heroes is one "cultural propensity" in the narrative of The King and I. This story responds to the innate love of heroes and heroworship in the American people. Since its original 1870 book to its 1956 musical incarnation, Anna is made to embody the above-mentioned characteristics of an American hero (Gross, v, 8, 34). In her dealing with the powers-that-be, namely the king in the story, Anna answers to her impulse to stand up for the ideals in which she believes. It is easy for the American audience to associate itself with her because, compared to the autocratic king, she is one of "the little people" like themselves. In comparison to her adversaries, she would appear to be powerless. Her distrust and fear of the king's power is evident at her first landing in Bangkok (The King and I, act 1, sc. 1). In order to reassure herself, she sings a makebelieve song, "I Whistle a Happy Tune," in order that she has something to console her. Even in Landon's book, the portrait of Anna as a "little person" fighting an imposing adversary is designed to elicit sympathy among readers.

[T] he slim figure of Anna Leonowens seems a little rigid as she moves between these flashing, colorful folk, we need only remember her constant need for courage and the strong sense of duty which gives her steel when it is necessary (E.M.B., Springfield Republican, February, 1944: 4d, emphasis added).

And yet Anna still puts up a brave front and courageously challenges the king as well as traditional Siamese practices that contradict American ideals of freedom. This is a reaction with which the American audience can identify itself. At the same time, they admire Anna in so doing. When she clashes with the king on the housing issue (which carries through the end of act I in the musical), Anna firmly stands her ground, admirably proclaiming that she cannot live in the country "where a promise has no meaning" (The King and I, act 1 , sc.4). Like the hero of American Western mythology, she is portrayed as a strong, independent character, seeking fairness and decency, and protecting freedom and liberty in a time and place in which there allegedly is no honor.

A more subtle ideological battle of these two opposing personalities later emerges 
over the issue of slavery, which is portrayed in the oppression of Tuptim and the king's cruel persistence in pursuing the fleeing woman and eventually punishing her. Anna's principled stance on this issue establishes her as a noble hero. She challenges the king to be "better" than his traditional inclinations, and not "to throw away everything [he] has done." Anna's courageous reaction further angers the king, and corners him into acting more assertively, when he retorts:

Am I King, or am I not King?

Am I to be cuckold in my own palace?

Am I to take order from English schoolteacher?

(The King and I, act 2, sc. 4).

In contrast to Anna's principled and heroic deeds, the king's savage action seems even more hideous.

This leads us to another angle of Anna's heroic character: her fight for the enslaved court ladies. This campaign, which is clearly emphasized in all versions of the narrative except for the 1951 musical and the 1956 film version, enhances her personality and turns her into an emulation of Abraham Lincoln, the Great Emancipator. Although Anna's "mission" of righting the wrong and freeing the enslaved is not as frequently displayed in the musical as it had been emphasized in the 1944 book and the 1946 movie version, there are more allusions to President Lincoln in the musical than in the original 1870 book version by Leonowens herself.

The most significant addition and allusion to Lincoln, "the Great Emancipator," is the ballet scene, "Little House of Uncle Thomas," which carries strong anti- slavery sentiments. By associating Siamese slavery with American slavery, the musical draws the audience's attention to the horror and cruelty that has been associated with American slavery. Because the details of the Siamese slavery system and the conditions of palace slaves are not accurately portrayed, the audience, doubtless to say, equates the two systems. In other words, given that the audience's only knowledge of slavery was the nineteenth century American variety, Siamese slavery and the Court, therefore, appear to be equally hideous and abhorrent. The audience cannot help but associate Anna and her attempts to free the Siamese ladies from the palace imprisonment, with President Lincoln as well. Thus, Anna Leonowens is portrayed as the Abraham Lincoln of Siam, who struggled to fight a similar war as the president was fighting at the time. The narrative, through the character of Anna, has struck at the heartstrings of American audiences and their belief in the corrupt forces that are trying to subvert the process of freedom and righteousness for which, they believe, America stands.

Moreover, the egalitarian ideal of natural rights for all men is echoed in Anna's exasperated argument with the king that "laws should be the same for kings and slaves" (Anna and the King of Siam, 1946). This statement carries a strong allusion to the cherished American concept of "government of the people, by the people, for the people." It reflects Anna as a hero with unwavering dedication to preserve fundamental American values. That the idea is incomprehensible or inapplicable in any society where kings and slaves co-exist eludes the audiences. They see in Anna the fragile embodiment of American 
ideals standing up strongly, and singlehandedly, against a much more powerful authority, who seems intent on asserting his absolute power over other characters, but is still unable to conquer Anna. Anna's battle, therefore, not only seems very logical and righteous, but also very heroic and noble. To the American audience, Anna has been transformed into a legendary hero.

\section{The morality-play appeal}

Another effective formula in popular literature is the use of a dramatic conflict between the forces of good and evil. Edith Efron in her analysis of a television show, "The Defender" (1962), mentions that several "high-rating dramatic shows" effectively employed this idea and turned their shows into morality plays, with the conflict between good and evil as their central dramatic conflict. Efron asserts that the idea that "ethics are a highly salable commodity in the world of drama" is not new. It has been employed to the advantage and profits of several box offices. Citing Reginald Rose, the writer and director of the television show "The Defender," Efron concludes that the audience was contented to see that justice had been well served, at least in drama.

Good drama always projects a writer's moral values. A dramatic plot is always the story of a moral struggle. Plot conflict is moral conflict.... The viewers remain secure in the knowledge that, before the hour is up, justice will triumph over the procession of high-minded lawbreakers and murderers (Efron citing Reginald Rose, 1980: 61).
Reginald Rose, the writer and director of this television show, had convincing evidence to substantiate his argument. Statistics showed that a show like "The Defender," where issues of morality and ethical dilemmas were central dramatic conflicts in each episode, was very popular among viewers. For example, $21,000,000$ viewers tuned in every Saturday night to watch it (Efron, 61).

Evidently the narrative of The King and $I$ also possesses this morality-play appeal. As a matter of fact, the constant battle of good and evil in this musical is multi-layered, more sophisticated, and brilliantly depicted. First of all, there is a superficial battle between the king and Anna. Anna is obviously made to be the paragon of goodness and righteousness, whereas the king is portrayed to be the oppressing force, who is trying to dominate her.

Secondly, there is an inner battle within the king himself. Audiences see in the king the dilemma of a man with split personalities. The musical maintains that the "good" part of him is willing to accept Western civilization and its ideals, as reflected in his attempt to modernize the country, and especially in his liberal ideas as expressed in the song, "It's a Puzzlement" (The King and I, act 1, sc.3). On the other hand, the musical also claims that another part of him, the "evil," still imprisons him with "uncivilized" practices and beliefs of his native culture and religion, which are antithetical to the virtues that Anna allegedly stands for. The intrigue is more than what the audience has anticipated in a show. However, at the end of the story, the audience is made to see for themselves that the king (the embodiment of evil) yields to Anna (the symbol of goodness). He meets the 
ultimate defeat: his death. ${ }^{1}$ The death of the king supposedly signifies the defeat of the evil. The good (as symbolized by Anna) prevails and is resurrected in the new king.

On a different level of interpretation, the clash of wits and ideologies between Anna and the king parallels with the sexual tension that they have to keep within bounds. It is apparent in the dancing scene (The King and I, act 2 , sc.4) that they are attracted to each other, at least momentarily. The allusion to this attraction is repeated in Anna's accusation that the king never really loves any of the women for he never loves anyone and never will (act 2, sc. 4). But, as John Lardner mentions in his review, "The Surefire Boys in Siam" (New Yorker, April 7, 1951, 27: 70-72), the king "keeps the obviously romantic nature of his feeling under pretty strict discipline." With such proximity and opportunity, a romantic relationship could have developed further from this mutual attraction, which is not at all impossible. However, both of them control themselves nobly. ${ }^{2}$ The audience sees them dancing and enjoying themselves

${ }^{1}$ King Mongkut of Siam (Rama IV, r. 18511868) contracted malaria during his expedition to investigate a total solar eclipse in a malaria-infested area in a southern province. The king was confined to bed for almost a month and passed away peacefully in 1868. The governess known as Anna H. Leonowens did not actually stay in Siam long enough to witness his death in person. She came to the Siamese Court in March 1862 and left for New York in 1867, presumably on a six-month leave. The king was not pleased to re-hire her. She never came back to Siam until her death in Canada in 1915. Her son, Louise, came back and prospered in the reign of $\mathrm{King}$ Chulalongkorn (Rama V, r. 1868-1910) who succeeded his father. in this enchanting moment, but no serious romantic relations developed from this episode. There is a brief moment of anticipation when Anna is waiting for the king's move, but he apparently wants only to dance with her in the Western fashion, putting his hand on her waist and gliding to the music. In seeing this, the audience is pleased with the nobility it has witnessed. Anna does not let a momentary romantic urge overcome her principles and sensibilities. The interracial line is not crossed. The goodness in their character has "triumphed over" the temptations of the flesh. Ethan Morddan states that it is a musical "in which the two central lovers never kiss, scarcely even touch." $\mathrm{He}$ also implies that this is one of many elements that make this musical one, if not the best, of Rodgers and Hammerstein's "Big Five:" Oklahoma, Carousel, Allegro, South Pacific, and The King and I. (Morddan, 1992: 145).

As mentioned before, the ending of the musical is crucial to its success. It fits the traditional narrative of good versus evil that the audience has anticipated (Scott, 1996: 234). It confirms the messages that good will triumph over evil, and that the Western way is "better" and more "civilized" and thus should be embraced. It also confirms the anticipated conclusion of the contest between the king and Anna. The king on his dying bed capitulates to Anna.

\footnotetext{
${ }^{2}$ In its latest version of Anna and the King (1999) starring Judy Foster as Anna and the Hong Kong star, Chow Yun Fat, as the King, the romantic undercurrent is more explicitly portrayed. The final tableau shows the young PrinceChulalongkorn voicing his sympathy as he watches his royal father dancing with "the woman he (the king) loves."
} 
He raises her salary, asking her to stay on to educate the new king, allowing the new Westernized manners and protocol into the court and thus into the country. The musical foreshadows this development in the dying scene by suggesting the influence that Anna has on the new king (act 2, sc. 6). While the whole assemblage pays homage to the Western modernity as symbolically promised by the new king, the evilness of the old system, supposedly, dies as the old king passes away unnoticed by the new generation.

\section{The democratic crusader appeal}

During the 1950 s, there was a dramatic rise of a combination of patriotism and religious zeal in American society. Numerous historians have attributed these sentiments to the spread of Communism and the fear of the Cold War. Patriotism and religiosity seemed synonymous. People were less tolerant of atheism and agnosticism, and equated them with Communism, the doctrine expounded in Marx and Engles' Communist Manifesto (1848).

America awoke to the 1950 s with the apprehension that the Communist threat was approaching and becoming more real. The fear of the Cold War and Communist invasion of America, which was wide- spread throughout the country at the time, was manifested in the "red scare" tactics of Senator Joseph McCarthy ( $R$, Wisconsin), following the persecution of Alger Hiss.

Hiss was a Harvard graduate who had held several prominent offices, including one in the Department of Justice from 1935 to 1936, and later in the State Department. The Hiss case began in 1948 when Whittaker Chambers, a self- confessed Communist who was a former Time editor, testified that Hiss provided him with classified documents between 1936-1938, all of which were transmitted in the department's most secret Code D. There were some microfilms (which were later called "the pumpkin papers" because Chambers hid them in a hollowed-out pumpkin) and 84 documents, 41 of which were memoranda written in Hiss's hand. In January 1950 Hiss was found guilty of perjury for his denial of charges of espionage and was sentenced to five years in prison (Manchester, 1974: 5-7, 509). But Hiss was only one among thirty-seven government employees in high office who were accused of participating in espionage for the Russians. The country was then engulfed with fearful apprehension that Communist spies had been lodged in the federal government's high offices for years without anyone's being aware of it (Manchester, 502).

This atmosphere of suspicion and paranoia paved the way for the rise of a demagogue who gave the decade the name "McCarthyism." In 1950 in Wheeling, West Virginia, Joseph McCarthy (then 41), a junior Republican senator from Wisconsin, announced in a Lincoln Day speech that he had, "a list of 205 that were known to the Secretary of State as being members of the Communist Party and are still working and shaping the policy of the State Department" (McCarthy cited in Manchester, 522). McCarthy was seeking an election campaign issue and was advised to use Communist hunting for his platform. That McCarthy never provided the list that he claimed to have in his possession, or, that he later changed the number to 57 and again later to 81 , did not matter to the general public. 
McCarthy could not provide any substantiation to his accusations of Communist affiliation in the State Department, and to many Americans McCarthy's charges were baseless (Manchester, 523). Indeed, in his book, Nightmare in Red (1990), Richard Fried maintains that McCarthy actually "didn't know a Communist from a street cleaner," even after being briefed by "experts" in communism "including Richard Nixon, Styles Bridges, J. Edgar Hoover, congressional staffers, and journalists" (Fried, 122-123).

By then, however, the issue had become fiercely partisan between Republicans and Democrats. Shielded by congressional immunity, McCarthy started his "red-baiting campaign," making unfounded charges against a large number of people in several circles as being Communists or Communist sympathizers, including United States Ambassador to the United Nations Philip Jessup, Generals George C. Marshall and Dwight D. Eisenhower (Nash, 1971: 406). The Tydings committee, a bi-partisan committee chaired by Senator Millard Tyding ( $R$, Maryland) to investigate McCarthy's allegations, was the first of five senatorial attempts to investigate McCarthy's charges against the "proCommunists." None of the committees found any evidence to support any of McCarthy's charges.

Nevertheless, McCarthy's reckless accusations and his mud-smearing techniques, which were described by a fellow Republican as "a forum of hate and character assassination sheltered by the shield of congressional immunity," had a greater impact on the society, which was to enhance the atmosphere of fear, suspicion, and pressure to conform (Ravitch, 1990: 302, 303).

More importantly, as William Manchester notes, "McCarthy had kindled a fire in America's grassroots." Despite his being exposed as a fraud and a liar by congressional committees, he had strong support from the general public. McCarthy received "pyramids of rumpled dollar bills and change," which totaled thousands of dollars (Manchester, 526; Fried, 127). In the 1952 election he scored best in the areas that had traditionally been Republican (Patterson, 1994: 334).

Certain happenings in the international political arena helped fuel 1950s antiCommunist tensions at home. In 1949 , China's Nationalist government, which was led by Generalismo Chiang KhaiChek and supported by the United States, fell to the Communist army led by Chairman Mao Tse-tung. In June 1950, South Korea, which was also supported by the Truman government, fell to the invading Communist North Korea, which was aided by the Chinese Communists (Clements, 1975: 193). This also gave rise to the concern that the Communists were gaining ground and closing in on areas of American influence. To concerned Americans, a Communist invasion seemed imminent and was merely a matter of time. In the congressional midterm-elections in November 1950, both the domestic and international situations were successfully manipulated as a campaign issue by Republicans who accused Democrats of being "soft on communism" (Morris, 1976: 517-518).

Amidst this red-scare atmosphere, many Americans needed reassurance. They turned to religion and expressions of patriotism. Douglas Miller and Marion 
Nowak in their intriguing book, The Fifties: The Way We Really Were (1978), contend that many Americans in the fifties believed that a new Christian civilization and a new Christendom, if any would ever come about, would be on America soil (Miller and Nowak, 84). During World War II, religious concerns became increasingly evident. After the war religiosity slightly declined before regaining its popularity again in the midforties and early fifties. Bible sales skyrocketed. Between 1946 and 1953 the yearly distribution of the Bibles rose to 143 percent. Biblical stories were retold in several different styles in syndicated newspapers and magazines, such as The Reader's Digest. Citing the results of several surveys, Miller and Nowak relate that church attendance soared in the early fifties. Sixty-three per cent of the population was officially affiliated with churches. Ninety-six percent of those who answered the questionnaires identified themselves as Protestant, Catholic, or Jewish (Miller and Nowak, 85-86). Theologian Will Herberg concluded that the three major faiths had come to serve as America's new "triple melting pot" when ethnic sub-cultures began to decline (Marchand, 1982: 174-176). The time was ripe for the American Legion to launch a well-publicized and wellfinanced campaign to bring the nation "back to God." Religions of the one Supreme God were identified with Americanism. These sentiments were solemnly proclaimed by President Eisenhower:

Recognition of the Supreme being is the first, the most basic, expression of Americanism. Without God, there can be no American form of government, nor an American way of life
(President Eisenhower cited in Miller and Novak, 85).

The president himself was regarded as exemplary of the new American "simple piety" although he was not an official member of any church until after his 1952 election. He asserted his idea of "simple faith" by advocating any faith. Politics and religion re-united in his assertion: "Our government makes no sense unless it is founded in a deeply felt religious faith, and I don't care what it is." Millions of Americans liked his simple piety, especially when he assured them that "America was "the mightiest power which God has seen fit to put upon His footstool" (Eisenhower cited in Miller and Nowak, 90).

Miller and Nowak also maintain that, despite the spirit of the separation of church and state as expressed in the First Amendment, politics and religion have always mixed in America, and it was the most evident in the fifties. For example, there was a "float of God" in the parade during Eisenhower's inauguration in 1953. In 1954, Congress enacted legislation adding the phrase "under God" to the pledge of allegiance. That same year they passed a bill authorizing the construction of a prayer room for Congressmen near the Rotunda on Capital Hill. In 1956, "In God We Trust" as a national motto unanimously passed the House and Senate without debate (Miller and Nowak, 87).

Understanding this cultural context of intense piety, religiosity, and patriotic fervor makes intelligible The King and $I$ 's emphasis - both in its theme and in its depiction of Anna's character-on religious and democratic ideals. Because Anna is not only an embodiment of 
American values and ideals, but also a Christian, the battle between Anna and the king, therefore, carries a multilayered significance. Superficially, it represents a general ideological clash between the democratic determination embedded in Anna's character, and the obvious autocratic stubbornness in the king. In the ballet scene (act 2, sc.3), this ideological battle is dramatized before the king. The judgment is clear in the ballet's narrative: the God-like Buddha is not on the king's side; the king is at fault and will eventually be conquered by the goodness represented by the enslaved crusaders led by Anna.

Moreover, the king is portrayed as a villain, not only because he is not a civilized democrat, but also because he is, by definition, a heathen. His religious zeal is made to look ridiculous. His prayer, which is nothing similar to a Buddhist prayer (Gedney, 1961: 84-85; DaGrossa, 1994: 92), is vulgar, nonsensical, sexist, and prejudicial.

Oh, Buddha, give us the aid of your strength and wisdom, And help us to prove to the visiting English that we are extraordinary and remarkable people. Help also Mrs. Anna to keep awake for the scientific sewing of dresses, even though she be only a woman and a Christian, and therefore unworthy of your interest

(The King and $I$, act 1, sc. 6)

In this particular scene, Christianity is identified - indeed, seemingly equatedwith the American ideals of democracy and freedom, as well as with the English language, which is the crucial tool for the acquisition of Western knowledge and technology, which the king himself aspires to learn. The English language has continually been utilized as a missionary tool to spread Christianity in non-English-speaking and non-Christian countries. In Landon's book, Anna tells the king that she cannot "teach English and omit references to Christianity" (Landon, 1944: 233). This sentiment was probably a reflection of a policy of the American Presbyterian Mission (to which Landon also belonged). In an article on "The Schools of Siam" (1884), Mrs. S. G. McFarland expressed exactly the same attitude when she mentioned the objective of establishing a Presbyterian school in Siam as a conversion tool. She was disappointed that some children were sent to learn English, but not Christianity. The missionaries were trying to win the trust of the Siamese and to assure them that "the missionaries labor[ed] for the highest welfare of the country." However, she reached the same conclusion as Anna that the English language and Christianity could be equated.

Christianity implies knowledge, and missionaries believe in schools."The Oriental mind is quick in childhood, but early stops its growth;" then to civilize and Christianize such a people the most hopeful plan is to begin with the children. [...] [A]nd how foolish it is for any one to suppose that the English language can be learned Without learning the religion of Jesus at the same time

(McFarland, 1884: 221-222, emphasis added).

Evidently Anna takes on the same stance as a Christian crusader who 
considers it her duty to "civilize and Christianize" the Siamese by teaching the language and religion at the same time.

However, by mis-representing Buddhism and putting it on the comparative scale with Christianity - as depicted in the prayer scene (act 1, sc. 6) - the musical is, seemingly, turned into a missionary tool. As a matter of fact, the tactic of condemning Buddhism and praising Christianity had been used by the missionaries in Siam before and during King Mongkut's reign (Bowring, 1969: 338-341, McFarland, 1884: 207-213). Approvingly quoting the French Diplomat de la Loubère, Bowring agrees that it was not a good tactic to condemn and insult Buddhism the way the missionaries were doing because it only served to offend the Siamese.

We want to make a tabula rasa and we fail. [...] [de La Loubère] says of the Siamese, they, with other Orientals, believe that different religions belong to different nations; they do not molest us in our opinions, why should we trouble them? Why should not the sages of the heathen be praised when praise is becoming? Why should their merits be concealed?

(Bowring, 341; 343).

But to the American audience unfamiliar with Siamese history or Buddhist teachings, the depiction of the king and the representation of Buddhism as ridiculous and nonsensical are an unfair and stereotypical display of the alleged flaws and falseness of Buddhism against the already-accepted excellence and superiority of Christianity.
Therefore, the underlying crusading appeal in this musical is reassuring and comforting to its audience. It also intertwines with the morality-play appeal discussed above. At least in this musical, the Christian and democratic Anna (the good) wins the battle, and the heathen autocratic king (the evil) is definitely conquered. A critic of Landon's book concluded that, "We follow their [the Orientals'] fates with much of Anna's emotion in our anxiety now and then, at least, to see tyranny the loser"' Ernestine Evans in Weekly Book Review p. 1, J 1, February, 1944). When the musical was revived in 1977, it was once again a Broadway hit. The audience again identified themselves with Anna and her "mission." They still felt contented with the narration, and the idea of Anna as a crusader coming to an allegedly barbaric land to win the nation to the more "civilized" ways of the West. One prominent critic stated that "the slow winning of the King to Western waysbuilds most satisfyingly" (Clive Barnes, The New York Times, March 15,1977: $50)$.

\section{The Oriental appeal}

It is obvious from most of the critical reviews of the books and the plays that one of the most important themes that has contributed to the popularity of the Anna narrative is its exotic "Oriental" setting, which according to one reviewer, represented "the richest vein of untapped material discovered in years" (Sterling North in Book Week, February, 1944: 2). Another critic associated the Siamese setting with the Tales of the Arabian Nights.

[T] he fascination of the story lies in the contrast between $a$ splendidScheherazade 
background and the tidyminded Victorian lady periodpiece. Seen through Anna's incredulous, indignant eyes, the suppressed inner life of the harem, the unspeakable cruelties, the lusts and the brazen color come to us as perpetual astonishment (IsabelleMallet in the New York Times ${ }_{2}$ September, 1944, p. 1, J.1, emphasis added).

In this regard, an article by Leslie Donaldson in The Magill's Survey of Cinema (First Series, 1980: vol.2, 897899) provides additional evidence of the musical's "Oriental" appeal. Donaldson maintains that exotic locales certainly contributed significantly to the success and popularity of several musicals at the turn of the century.

The Western fascination with Oriental things and people is actually voiced in the song, "Western People Funny" in this musical, when Lady Thiang voices her indignation that Western people "feel so sentimental about the Oriental" and that they try to turn them (the Oriental) "inside down and upside out" (act 2, sc. 1).

The idea of Oriental exoticism and how it has been stereotyped as expressed above is consistent with Edward Said's contention that the Orient is labeled as "a living tableau of queerness" (Said, 1979: 103). As mentioned in the song, "Western People Funny," there is something fascinating about the Orient that triggered curiosity among the Western people. Perhaps it was their differences from the familiar Western people and locales. However, Said argues that the Orient that interested the West "is not the Orient as it is, but the
Orient as it has been Orientalized" (Said, 104). This is particularly true in the case of The King and I, especially when we have Rodgers' testimony that he recreated this musical from his own interpretation of Siamese culture without any particular intention of achieving historical and cultural authenticity. (Rodgers, 1975: 270) The Siamese scenes that were so fascinating to the critics are, therefore, "Siamized" scenes as invented by Rodgers and Hammerstein. The result is a spectacular stage performance with "all scent and glitter, ritualized movement and high barbaric style" (Time, April 9, 1951, 78).

At least one of the "Orientalized" or "Siamized" aspects of this musical was noticed by The New Yorker's critic, John Lardner. He makes an insightful observation about the language of the characters.

Mr. Hammerstein's version isdistinctly in his own styleexcept, perhaps, that the characters who are theoretically Siamese, which means all but half a dozen members of the cast, speak thesort of pidgin English that is used on stage and screen for the presentation of every kind of foreigner from Kurd to Eskimo, and that calls blindly for the elimination of "the" " "to whom I pay vast sum of twenty pounds a year") and of the introductory "it" ("Is a puzzlement").

(April 7, 1951, 70-72, emphasis added).

Lardner's remark about the "pidgin English" spoken by foreigners on stage 
is interestingly true. There are more than enough of such examples on screen and on stage to support his observation. This is one of the "stock" characteristics of Orientals as "Orientalized" by American producers and directors who do not care to differentiate among Asian linguistic differences that might affect in different ways the manner in which they pronounce English. However, it is doubtful that many people in the audience were as perceptive, in this regard, as Mr. Lardner.

But what is more significant in this musical is not only the exoticism of the setting, the costumes, the language and the "strange" characteristics in the play. Even more compelling is that its Oriental-ness allows the story to be readily accepted by the audience as convincing and logical. Because of the general belief in Western cultural hegemony, that the West is "superior and more civilized" (Said, 7), the audience is prepared to believe that this story must have happened the way it has been told. Not many people in the audience would stop to question its authenticity or to check the historical basis for it. The play and the musical are so effective and compelling in their characterization of the cultural contrasts between East and West that the audiences would instantly accept the narrative as it is told, and the characters as they are depicted. Movie critic DeWitt Bodeen's comments on the movie Anna and the King of Siam (1946) supports this argument.

[I]n his first speech, [the new king] frees all his people so that none can hold another in bondage.This is all based upon the actual truth, for without

\begin{abstract}
Anna and her wise counseling the country of Siam might have remained backward, never becoming a land where free men and women walk

(Bodeen, 80, emphasis added).
\end{abstract}

Bodeen also maintains that Rex Harrison carries himself more like a "monarch schooled in the best tradition of Oxford rather than the royal court of Siam" (Bodeen, 81). Most of the critics' reviews of the 1951 musical supported this statement. They found Yul Brynner's performance superb and splendidly done, which supports the contention that his interpretation of the king's character met the audience's expectation of an Oriental king. No critics expected an Oriental king to be capable of reserved manners and composed anger, while Anna was expected to be proper and sober-minded, "as a Victorian rebel in a barbaric land" (Newsweek, April 9, 1951,73).

It would be interesting to see the audience's reaction if a similar play were to be produced with Anna trying to "civilize" an American president. Or better yet, if the exact same play were to be produced with reversed roles and locale. Instead of an English woman trying to educate a Siamese king, we could have a Siamese woman trying to educate an English king at an English court. This is a hypothetical question that will never be answered. But its impossibility also reinforces the point that Rodgers and Hammerstein's "Siamized" characteristics of this musical have significantly contributed to its success and popularity. 
The characteristics discussed above are prominent "cultural propensities" in the Anna Leonowens legend. They are elements that have been effectively employed to engage, appeal to, and intrigue the American audience of the several incarnations of the musical The King and $I$. The next question is: how are these "cultural propensities" used by the entertainment industry in the recreation of the legend of Anna?

\section{The Role of Popular}

\section{Entertainment Industry in the Perpetuation of Anna's Legend and Myth}

In his book, Lawrence of Arabia and American Culture (1995), Joel Hodson provides a very interesting and insightful paradigm with which to consider the legend of Anna Leonowens. His analysis examines the rise to mythical status of T. E. Lawrence (1888-1935), a British soldier in the First World War, whose transatlantic legendary image was perpetuated by the machinery of popular culture and the popular entertainment industry in a fashion similar to that of Anna Leonowens. Hodson's analysis and discussion of the process of Lawrence's transfiguration and of the propagation of the Lawrence of Arabia legend provide an instructive model for considering the transformation of Anna Leonowens into an American legend. It also suggests parallel aspects of the propagation processes of these two myths in American society. It further demonstrates how the four cultural propensities in The King and I (as discussed above) have also been utilized to perpetuate the Lawrence of Arabia legend as well.
Like Ian Scott in his discussion on the significant role of Hollywood in the creation of modern-day heroes (Scott, 1996: 232-239), Hodson maintains that the popular culture industry plays an important role in the general propagation of modern-day legends and myths. In the early 1920s, Lawrence of Arabia was depicted as "a modern-day Richard Lion-Heart" and was regarded as "a character model for English-speaking school boys," establishing his image "in flowing Beduin robes [...] in the imagination and memory of the public" while his other contributions to British nationalism have already been forgotten (Hodson, 1995: xi, 1).

In his analysis, Hodson traces the career of T. E. Lawrence's "popularizer," Lowell Thomas, the American journalist, adventurer, and former war correspondent during the First World War. Thomas played a crucial role in the propagation of the Lawrence of Arabia image, mostly through his lectures and traveling displays of the story of Lawrence entitled, "With Allenby in Palestine and Lawrence in Arabia." The lecture was reportedly "unusually successful."

[T]he program was a phenomenal success around the world. In England, it received rave reviews, and over a million of Britons flocked to see it. The box office sometimes netted $\$ 2,000$ a week profit. Thomas received guest-ofhonor invitations and the gratitude of prominent government officials. A luncheon in his honor was sponsored by the EnglishSpeaking Union, and the queen 
attended one of hisperformances. (Hodson, 42).

Although Lowell Thomas was not the only author of the Lawrence of Arabia legend, he became, literally, Lawrence's "popularizer" because of the popularity of his shows, even though the story of his life and his contribution was full of "inaccuracies and hyperbole." In his three-installment 1919 magazine article, "War in the Land of the Arabian Nights," Thomas' sub-title of the first installment as "Lawrence-Prince of Mecca" successfully established the image of Lawrence as an Arabian prince. Even Winston Churchill made the allusion to Thomas' appellation of Lawrence, in his writing about Lawrence, saying that he "looked what he was, one of nature's greatest princes" (Hodson, 36-40).

According to Hodson, the success of Lowell Thomas's Lawrence of Arabia lectures and the re-creation of the legend can be attributed to both the contents and techniques of its presentation. Thomas combined several aspects of entertainment, including photographs, film footage, stage entertainment, music and narration, to create the so-called modern vaudeville performance serving as both entertainment and reportage (Hodson, 41).

Apparently, the "Oriental" effects, generated by the combination of "veiled dancers, film footage of Sudanese minstrels, incense and organ music as well as a commercialized rendition of the Islamic call to prayer" (Hodson, 42 ), were successfully manipulated in the presentation, adding to the alreadyOriental subject matter. Thomas effectively employed certain other elements. First, he invoked his audience's love of heroism and heroworship sentiments. Despite his small stature and boyish appearance, Lawrence was projected as a superhero with "superhuman ability and a mythic quality." Thomas popularized him as "a shy but heroic Oxford scholar-turnedwarrior" (Hodson, 40). This suggests the innate nobility and gentility of his character-that he was not at all a natural savage or war-mongering soldier by nature or by profession. His mission in the Arabian deserts, therefore, became a noble mission that he felt obligated to pursue. In the process, the Arabs were portrayed as "childish," and thus needed the Westerner Lawrence's "protection." Thomas also re-created villains for his hero to vanquish - the Turks and the Germans. Lawrence became "the uncrowned king of Arabia," and "the terror of the Turks," who could "blush like a school girl" (Hodson, 36).

In addition, Thomas's performance served as a reunion for "war heroes" in real life-veterans of the Middle East campaign - who were delighted to see their own part in the war recorded, publicized, and disseminated to the general public. Hodson contends that the post-World War I mood also contributed to its success. It was a time when people did not want to hear about the horrors of the war, but they loved to reminisce about its glories.

They wanted to hear about Allenby the Crusader, the conquest of the Holy Land, and, in particular, the mystery man of Arabia. And they wanted to hearLowell Thomas, who had been there and "witnessed" the action,tell about it.

(Hodson, 43, emphasis added). 
Thus emerged another salutary effect that contributed to the successful propagation of Lawrence's mythic image: the underlying biblical allusions and the biblical setting of the story. It drew support from several religious groups. The interplay of the biblical allusions and the audiences' desire to "witness" the recreated incidents are evident in Hodson's discussion. These two elements increased the credibility of Thomas's story of Lawrence of Arabia.

From the lecture-performance by Lowell Thomas, the commercialization of the Lawrence of Arabia myth was expanded by the 1962 filming of Lawrence of Arabia, a joint production of Columbia and Horizon Pictures of London, starring the Irish actor, Peter O'Toole, as Lawrence. Its producerdirector team, Sam Spiegel and David Lean, had played similar roles in the highly successful movie, Bridge on the River Kwai (1957).

The usual mechanism of Hollywood came into play in the distortion of T. E. Lawrence's life as depicted in this movie. According to his brother, A. W. Lawrence, the production company had turned the movie into another mythical American Western with "a cowboy-andIndian style treatment," trying to tell an adventure story "in terms of a psychological study which is pretentious and false." The in-authenticity of the movie verged on the brink of indecency. Robert Bolt, the screenplay writer, depicted T. E. Lawrence as a homosexual, because of his lack of interest in women and his admiration for young men, despite contradictory information from other sources (Hodson, 122-123).
Hodson also maintains that the movie Lawrence of Arabia is "one of many examples of Hollywood distortions of history and biography." Moreover, it contributes to, confirms, and reinforces stereotypical images of the Arabs. Quoting Gary Crowdus, film critic and editor of Cineaste, a magazine devoted to the arts and politics of the cinema, Hodson concludes that:

[t]he Spiegel-Lean epic [of Lawrence of Arabia] also disparaged the Arabs, propagating the old Western stereotype of the Arabs as subservient, savage,comic, and incapable of ruling themselves, thus pandering to the preconceived notions of Western audiences. The viewing public, however, was not particularly interested in whether Lawrence of Arabia was a racist film or a historically misleading one (Hodson, 123, emphasis added).

Hodson also mentions that the historical distortions in this movie were intentional because the producer had several historians working for the company as researchers and advisers. Accessibility to historical and cultural facts was not at all their problem. The intentions of the producer were apparent in Spiegel's reply to the statement of Lawrence's brother printed earlier in the New York Times. Spiegel stated that, "We think life should imitate art, and not the other way round" (Spiegel cited in Hodson, 123).

This discussion on the propagation of the Lawrence of Arabia myth by the entertainment industry suggests a strong resemblance to the process of the propagation of the Anna Leonowens 
legend. The four cultural propensities discussed earlier - the hero-worship, the crusader allusion, the morality-play, and the Oriental appeals - have been effectively employed in the case of the Lawrence of Arabia myth. The differences between the two propagation processes lie merely in details of the subjects, setting, and narration.

To begin with, Anna Leonowens did not need Lowell Thomas to help propagate herself as legend. She acted, efficiently and effectively, as her own "popularizer." She wrote the accounts of her own experiences at the Siamese Court, which were published by the Atlantic Monthly in 1870 and 1872 . In between writing, she gave lectures, repeating her Siamese tales as well as her re-created life history. Her legend and its related tales were firmly established. When she moved to Halifax, Canada, to live with her daughter's family, her literary fame in New York had preceded her. Anna, who was considered "an exotic addition" to the city, was invited to tell her story time and again and was paid as high as $\$ 60$ for a lecture (Smith Dow, 79).

Comparable to Lowell Thomas's lecture on T. E. Lawrence, Anna Leonowens' tales reinforced the "preconceived notions" of Western audiences, as mentioned by Hodson about the Lawrence of Arabia myth. In Anna's case, she drew on the exotic Orient and the glamorous but 'heathen' Court of Siam for her materials. However, the fundamental themes of her tale were similar in many respects to those of the Lawrence of Arabia myth. Her story was a usual "cowboy-and-Indian style," with Anna herself as its hero, and the king and his court as the villains.
Although she was not battling to win the Holy Land from the infidels as Thomas had portrayed in Lawrence of Arabia, Anna had undertaken as important a task, for she had extended the arm of Western civilization and the light of Christianity to an allegedly barbaric, enslaved and uncivilized people. In Anna, Leonow ens'case, she had been there to experience everything in person. Her legitimacy and credibility to tell the story were thus seemingly equal - if not more-than Lowell Thomas' in his Lawrence of Arabia venture.

The next popularizer for Anna was Margaret Landon. Comparatively speaking, she was a Lowell Thomas for the propagation of the Anna Leonowens legend. It was Landon's book (1944) that established the history of Anna's early life, which Leonowens herself chose not to mention in any detail in her first book (1870). Landon's experiences in Siam during her ten years of living there, as well as her association with the Presbyterian mission in Siam, added new elements and greater depth to the character of Anna in the story, making her more devout, thereby enhancing admirable facets to the already-noble Anna. Landon's real-life experiences in Siam as well as the claim that she had access to personal additional information from Anna's granddaughter, Avis S. Fyshe, bolstered her claim of veracity that the story was "seventy-five percent fact, and twenty-five percent fiction based on fact" (Landon, 1944: 360). But because her so-called "facts" were derived from Leonowens' own reconstructed and romanticized "facts," the results were largely romanticized myth. 
The Hollywood distortions of history and biography began with the 1946 filming of Anna and the King of Siam (starring Rex Harris and Irene Dunn) by the Fox Studio (which would later produce the 1956 musical film as well) under the administrative control of Darryl F. Zanuck, who was well known for his imposing and weighty "suggestions" on his producers and directors. After reading the script of the film, Zanuck stated "on the record" in his memo to the producer, Louis Leighton, that it would make the best picture of the year because it was "something entirely original and [had] great quality" (Zanuck in Behlmer, 1993: 88). After all, Zanuck was an "expert" in making "biopics," biographical films of famous characters (Custen, 1997: 27). He wanted to create the film's "rooting interest," a critical incident, or special qualities which would ensure that the famous person's life would be clearly defined for the audience. The multi-dimensional narrative of Anna and the King of Siam (1944) with numerous descriptive passages was thus adapted to become more tightly focused in the 1946 film.

From Zanuck's memo, it is evident that an alteration of the tone and the narrative style emerged with this film version. Leonowens' own writing was dry and humorless, portraying an English governess with an "hauteur" attitude towards her employer, his custom, and his people. In Landon's version, we see a serious and conscientious governess who was liberated, but pious, and more feminine. Her writing was stylistically "lighter" and descriptively more engaging than Leonowens'. However, there was nothing hilarious in her accounts. But the film script for the 1946 version was, according to Zanuck, "very funny."

The comedy possibilities are enormous. This picture, with all its tenderness and conflict is basically one of the funniest I have ever read. It is genuine comedy because it comes out of the characters themselves and is a result of clashes of personalities. The incidents you have used for comedy purposes are wonderful. [... I I still feel that the king, almost as an afterthought on his deathbed, should give Anna a raise which he would not give her for forty years. [. . .] The banquet for the foreigners is riotious. The letter to [President] Lincoln, etc., etc., are wonderful moments

(Zanuck in Behlmer, 88, emphasis added).

Zanuck's memo points out to us several of the alterations that occurred in the process. The incidents Zanuck mentions in this memo are all variations from Landon's version, which itself represents an adaptation and elaboration of the Leonowens' version. However, Anna did not get a raise (in salary) in this movie version. She had to wait for another five years, until she finally got the raise in the 1951 musical film version. Nonetheless, the comic tone of this movie version was established and was retained in the 1951 and 1956 versions.

Another revelation that we learn from Zanuck's memo is that people in the entertainment business anticipated that this film would become a highly profitable commodity. Everybody, from directors to actors and actresses, 
wanted to have a part in its production (Behlmer, 89).

George Custen in Twentieth Century's Fox: Darryl Zanick and the Culture of Hollywood (1997), studies the influence of Zanuck and his studio on the production of Hollywood films. He mentions that a producer like Zanuck had "far greater influence and impact on a film than audiences would have realized." His "suggestions" and reactions to a script called for immediate adaptation and thus alteration of the original script, no matter what that might be. Quoting a reporter who had been observing Zanuck at a story conference, Custen agrees with the reporter that by the time the film appeared on the screen the character's viewpoints as expressed in the film, was already Zanuck's (Custen, 190).

Zanuck's impact on films was derived from his keen sense of the interests of the American audience. Although he lived in southern California (Los Angeles area) where films were usually previewed, he knew the kind of audiences he would need to deal with. Born and raised in Wahoo, Nebraska, he often imposed on his films Midwest small-town attitudes and values, which were recognized as fundamentally American. Custen contends that Zanuck's insight about his audiences was one of many factors that had made him one of the most successful studio managers of his time (Custen, 27-28, 189).

Zanuck's intervention was probably an explanation why the 1946 Anna and the King of Siam differed so much from Landon's book. The story was greatly altered, especially its ending, which is very significant to the theme and the messages of the film. Anna's importance to the Siamese Court was very much enhanced by the ending of the film, which emphasized the legacy of her contributions to the country. The 1946 film version then served as a key popularizer to the perpetuation of Anna's legend.

Then came the 1951 musical version of The King and $I$.

The musical represents the prototype of the modern popularizer of the Anna legendary myth. The obscure governess, whose image had been vaguely portrayed in two books and a black-andwhite picture, had received a color treatment, both in her characterization and in its presentation on stage. Anna was transformed into a glamorous personality. Theatrical effects made her character seem more "real" to her audience because then people could hear her "say" the actual words in front of them. The audience had actually "witnessed" the occurrences in the Siamese Court as presented to them on stage. The theatrical illusions work to gain the audience's approval - or greater approval-of Anna's character. Compared to Lowell Thomas's performance in "creating" Lawrence of Arabia, this was what the audience cherished - the idea of "being there" in the midst of the re-created "mission" and being part of it (Hodson, 1995: 43).

The most enduring popularizer of the Anna legend is the 1956 film version of the musical. Here we can see the cumulative impact of the popular entertainment industry on its end product. The musical film is similar to the 1951 stage version. However, there are several changes once again made to comply with "suggestions" from Fox's 
mogul, Darryl Zanuck. This time, as evident from his October 1954 memo to Rodgers and Hammerstein, as well as to the film's producer, Charles Brackett, Zanuck was more concerned with the length of the film. He revealed that for the 1946 movie version, he needed to waste "three reels of finished film" in the process of trimming it down to a running time of two hours and eight minutes. Therefore, he "suggested" that the creators of this musical film plan the shooting with regards to time constraints so that they would not have to waste "thirty minutes of hard-earned film." (Behlmer, 250)

Following his suggestions, Rodgers and Hammerstein cut six songs from various scenes, which changes the voice and slightly shifts the emphasis of the musical from those of the 1951 stage version.

Because of its accessibility, the 1956 musical film double-functions as a repeated reminder of the Anna legend. This movie version often brings back the already-cherished Anna into American homes, with its frequent reruns on television and its availability on videocassettes. The glamour of the Court, as well as its uncivilized and backward character, has been displayed time and again for new generations of audiences. While Anna's mission remains fundamentally and ideally American, the alleged backward-ness of the Siamese Court has seemed even more primitive by comparison.

For example, un-informed audiences in 1977 may not have recognized that when Anna was preaching anti-slavery (in Siam) on Broadway in 1951, America had not yet even begun to fight the racial legacy of its heritage of slavery. And for the American audiences of the 1977, who had just experienced the Civil Rights and the Women's Liberation movements, slavery was a hideous practice with painful and long-lasting negative effects on the life of a nation.

They associated Siamese slavery system as portrayed in the musical and the film with American slavery. Then they imposed the judgment of their time on Anna and the Siamese society as presented to them. The stereotypical image of the Siamese people, society and monarchy remained horrendous, if not worse, in their opinion. The legendary image of the righteous Anna, as imprinted upon celluloid, had been established in their minds and would be difficult, if not impossible, to eradicate. As one critic said in a 1977 review on the revival, "It is essentially the imperishable material that makes The King and I one of the great musicals of theater history" (Variety, April 15, 1977, 140).

It is noticeable that in the production processes mentioned earlier, either by Rodgers and Hammerstein or Fox Studio, none of the production companies expressed concern about the veracity of the story. The emphasis is more on the marketability of the end product than the authenticity or veracity of the legend itself.

Evidently the legend of Anna Leonowens has traveled a path similar to that of Lawrence of Arabia, a path paved by the entertainment industry. In his discussion of Hollywood and its creation of legendary figures, Ian Scott contends that these two myths are just a fraction of the industry's creative business, which is intent on re-confirming what the American audience wants to believe about itself and about American ideals. 
In so doing, Hollywood producers seek to portray leading characters of American Westerns as strong, tough, and independent "sometimes within the law, sometimes outside it, but [men] who always sought order, fairness and decency." Therefore, a movie production often follows a formula to satisfy the audience's expectations.

Their characters trod a righteous path which sought to protect freedom and liberty, to present honorable principles in a time and place in which there was no honour. In order to do this, of course, a myth had to be created which set up the conflict between the righteous and needy and the evil and corrupt. In so many Western settings, the backdrop was always another Tombstone - or a town just like it - that always needing saving, if not from itself then from the outlaw fraternity that inhabited it

(Scott235, emphasis added).

We have a long list of American Western movies to verify how such a formula has been manipulated by the American entertainment industry, especially in its perpetuation of modernday myths. It also confirms the impact of Hollywood's moguls, such as Darryl Zanuck, on the culture of Hollywood and the shaping of American society, through the industry's intentional oversimplification and downright distortion of complicated historical facts. In his analysis of the industry, Custen contends that "popular entertainment was sometimes formed out of manipulation, theft, and misappropriation." And yet it creates images with a significant social agenda, the images from which audiences formed their beliefs, "whether or not they were historically accurate" (Custen, 205, 200). The King and I is merely one prime example of such occurrences.

\section{Conclusion: The American Dream Re-confirmed in The King and I.}

The story of The King and I is actually another American success story. Instead of ordinary material success in the Horatio Alger's rags-to-riches fashion, this story contains a higher value because it is a manifestation of a successful cultural mission, singlehandedly performed by a fragile, but courageous young woman who, though British by birth, possesses all the righteous characteristics which were ideally "American," with which the American public want to identify themselves.

The legend of Anna Leonowens was thus the re-confirmation of the existing ideals that Americans wanted to strive for. To see these ideals expressed on the screen or on the stage was to reassure themselves and reaffirm those "American" characteristics that they cherish. They do not concern themselves whether the characters have been realistically portrayed or whether the circumstances are authentic. They only need reassurance, and the entertainment industry, as evident in the case of, The King and $I$ is always ready to perform that task to satisfy them. By incorporating into the story cultural propensities with which the audiences are familiar-and highly value, the popular entertainment industry has been successful in reading the mind of their 
target audiences and continuously reaping profits.

However, in the case of a fictionalized story as popular as the musical The King and I, the producers' claim to complete historical veracity while simultaneously being aware of the additions and adaptations made by their own studios is inappropriate and irresponsible. By stereotyping a culture and a nation in such an appealing and memorable way, the industry has committed a cultural crime. The industry, with utmost subtlety and insensitivity, has helped instill and reinforce in the public's mind the prejudicial notion of "the Other." In this way, the industry not only satisfies or reassures the American public of what and who they are, but also indoctrinates crucial values and assumptions in their audiences, "coaching" them how to look at people of different cultural heritages. This, the audiences have learned to do without even realizing it. In the case of The King and I, the industry has enjoyed half a century of acclaim and profits at the expense of a respectable monarch, his culture, and his people.

\section{References}

Anna and the King of Siam. 1946. Dir. John Cromwell. Perf. Rex Harrison; Irene Dunne; Linda Darnell; Lee J. Cobb, and Gale Saundergaard. Twentieth-Century Fox.

Barnes, Clive. The New York Times, March 15,1977: 50.

Behlmer, Rudy. Ed. 1993. Memo from

Darryl F. Zanuck. New York: Grove Press.

Bowring, John, Sir. 1969. The Kingdom and People of Siam. Kuala Lumpur: Oxford University Press.
Clements, John. 1975. Chronology of The United States. New York: McGraw-Hill Book Company. Custen, George F. 1997. Twentieth Century's Fox: Darryl Zanuck and the Culture of Hollywood. New York: Basic Books.

Da Grossa, Pamela.1994 "The King and $I$ : East and West, Men and Women," In Literary Studies: East and West. . Honolulu : University of Hawaii.

Donaldson, Leslie. 1980 "The King and I" in The Magill Survey of Cinema. . First Series. Vol. II ed. Frank N. Magill, Englewood Cliffs, NJ: Salem Press.

Efron, Edith. 1980 "The Eternal Conflict of Good and Evil," TV Guide the First 25 Years. . Jay Harris, ed. New York: A Plume Book.

Evans, Ernestine. 1944 in Weekly Book Review. p. 1, J 1, February.

Fried, Richard M. 1990. Nightmare in Red. New York: Oxford University Press.

Gedney, Williams J. Translated and edited. 1961. Life and Ritual in Old Siam. by Phya Anuman Rajadhon. New Haven, CT: HRAF Press.

Goldberg, Michael G. ed. 1993. Thomas Carlyle:On Heroes, HeroWorship \& the Heroic in History. Los Angeles: UCA Press.

Gross, Theodore L. 1977. The Heroic Ideal in American Literature. New York: The Free Press.

Hodson, Joel C. 1995. Lawrence of Arabia and American Culture. Westport, CT: Greenwood Press. 
Kelly, R. Gordon. "Literature and the Historian," American Quarterly. Vol. 26: 2, 145-159.

Landon, Margaret. 1944. Anna and the King of Siam. New York: The John Day Co.

Lardner, John. "The Surefire Boys in Siam," in The New Yorker. 27: pp.70-72, April 7, 1951.

The King and I. 1951. By Richard Rodgers and Oscar Hammerstein II. Dir. John van Druten. Perf. Yul Brynner; Gertrude Lawrence; St. James' Theatre, NY. 29 March

The King and I. 1956. Dir. Walter Lang. Perf. Yul Brynner; Deborah Kerr; Rita Moreno; and Terry Saunders, Twentieth-Century Fox.

Mallet, Isabelle. In the New York Times, September, 1944, p. 1, J.1.

Manchester, William. 1974. The Glory and the Dream. Boston: Little, Brown and Co.

Marchand, Roland. 1982. "Visions of Classlessness, Quest for Dominion: American Popular Culture, 19451960," Reshaping America: Society and Institution, 1945 1960. Ed. Robert H. Bremner and Gary W. Reichard. Columbus: Ohio University Press.

McFarland, S. G. 1884. "The Schools of Siam," Siam and Laos as Seen by Our American Missionaries. Philadelphia: Presbyterian Board of Publication.

Miller, Douglas T. and Marion Nowak.1977. The Fifties. Garden City: NY: Doubleday.
Morddan, Ethan. 1992. Rodgers and Hammerstein. New York: Harry S. Abrahms Inc., Publishers.

Morris, R. B. 1976. Encyclopedia of American History: Bicentennial Edition. New York: Harper \& Row, Publishers.

Nash, Gerald.1971.The Great Transition. Boston: Allyn \& Bacon, Inc.

Newsweek, April 9, 1951, p. 73.

North, Sterling. In Book Week, February, 1944: 2.

Patterson, James T. 1994. America in the Twentieth Century. New York: Harcourt Brace College Publishers.

Ravitch. Diane. 1990. The American Reader. New York: Harper Collins Publishers.

Rodgers, Richard.1975. Musical Stages. New York: Random House.

Rosenberg, Bernard and E. Harburg. 1993. The Broadway Musical. New York: New York University Press.

Said, Edward. 1979. Orientalism.New York: Vintage Books.

Scott, Ian. 1996. "Mr. Innocent Goes to Washington: Hollywood and $\mathrm{T} \mathrm{h}$ e Mythology of American Politics," Representing and Imagining America. Ed. John P. Davies. Keele, Staffordshire: Keele University Press.

Smith Dow, Leslie. 1991 Anna Leonowens: A Life Beyond THE KING AND I. Nova Scotia: Pottersfield Press.

Time, April 9, 1951, 78.

Variety, April 15, 1977, p. 140. 